\title{
Processing of Mg-3.2 Al-2.4 Zn Alloy Matrix In-situ Composites by Reactive Infiltration Technique
}

\author{
Mohammad Tusar Ali , Kazi Mohammad Shorowordi \\ Department of Materials and Metallurgical Engineering, Bangladesh University of Engineering and Technology (BUET), Dhaka, Bangladesh
}

Email address:

tusarim05mme@yahoo.com (M. T. Ali), kmshorowordi@mme.buet.ac.bd (K. M. Shorowordi)

${ }^{*}$ Corresponding author

\section{To cite this article:}

Mohammad Tusar Ali, Kazi Mohammad Shorowordi. Processing of Mg-3.2 Al-2.4 Zn Alloy Matrix in-situ Composites by Reactive Infiltration Technique. American Journal of Mechanical and Materials Engineering. Vol. 2, No. 2, 2018, pp. 21-27.

doi: 10.11648/j.ajmme.20180202.12

Received: June 12, 2018; Accepted: July 17, 2018; Published: August 7, 2018

\begin{abstract}
Mg}$ alloy matrix composites having a combination of their indispensable and superior properties have drawn an attention for various implementations especially in automotive and aerospace industries. $\mathrm{Mg}$ in-situ composites were synthesized using $\mathrm{Mg}-3.2 \mathrm{Al}-2.4 \mathrm{Zn}$ alloy ingot, coarse $\mathrm{Ti}$ and $\mathrm{B}_{4} \mathrm{C}$ powder. Ti and $\mathrm{B}_{4} \mathrm{C}$ powders were mixed in a plastic bottle with zirconia balls in Ar atmosphere by ball milling. The resulting mixture of these powders was compacted into a cylindrical preform which was infiltrated by $\mathrm{Mg}-3.2 \mathrm{Al}-2.4 \mathrm{Zn}$ alloy under capillary force. The infiltration of the preform was performed in an electric resistance furnace at the temperatures of $800^{\circ} \mathrm{C}$ and $900^{\circ} \mathrm{C}$ for different holding time in Ar atmosphere. The microstructure of the in-situ composites was investigated with a field emission scanning electron microscope (FESEM) equipped with Energy Dispersive X-ray (EDX). The formation of phases in the in-situ composites during processing was identified using XRD with $\mathrm{Cu} \mathrm{K} \alpha$ radiation. SEM revealed different phases in the in-situ composites. It was found in XRD pattern that $\mathrm{TiC} \mathrm{TiB}_{2}, \mathrm{TiB}, \mathrm{MgB}_{2}, \mathrm{MgB}_{4}, \mathrm{~B}_{13} \mathrm{C}_{2}$ and $\mathrm{Ti}_{2} \mathrm{AlC}$ compounds were formed during infiltration of Mg-3.2 Al-2.4 Zn alloy matrix in the composites. The effect of processing parameters on bulk density and Brinell hardness was also discussed.
\end{abstract}

Keywords: Mg Alloy, In-situ Composites, XRD, Bulk Density, Hardness

\section{Introduction}

$\mathrm{Mg}$ alloy has been considered as a potential matrix material for metal matrix composite (MMC) for its lightweight properties i.e. pure $\mathrm{Mg}$ is $35 \%$ lighter than $\mathrm{Al}$ and over four times lighter than steel [1-3]. Ceramic particles reinforced $\mathrm{Mg}$ alloy $\mathrm{MMCs}$ has been effective for the automotive and aerospace applications because of having their high specific modulus and high wear resistance, low coefficient of thermal expansion, tensile strength and excellent electrical and thermal conductivities [4-8]. The fabrication of the composites with isotropic properties can easily be achieved by reinforcing the particulate as reinforcement in the composites. However, the properties of MMCs depend upon the particle stability, volume fraction, size, particle bonding with the matrix and extent of dispersion in the matrix. Conventional methods are known as ex-situ process, such as powder metallurgy, spray deposition, mechanical alloying, preform infiltration and various casting methods such as rheocasting, squeeze casting and compocasting have been generally used to fabricate $\mathrm{Mg}$ alloy MMCs. The interface characteristics between matrix and reinforcement have the significant effects on the properties of the composites fabricated by these ex-situ processes.

In the in-situ process, reinforcement particulates in the matrix metal alloys are formed by the reactions of the starting materials during processing. The formation of ultra-fine homogeneously dispersed and a thermodynamically stable ceramic reinforcement with clean reinforcement-matrix interfaces in-situ MMCs exhibit excellent mechanical properties [9-10]. $\mathrm{TiC}$ and $\mathrm{TiB}_{2}$ ceramic particles having high melting points, good thermal and chemical stability, high hardness, low densities and excellent wear resistance are considered as good potential reinforcing elements for $\mathrm{Mg}$ alloy matrix [11-12]. Moreover, $\mathrm{TiB}_{2}$ is considered as a proper reinforcement for their coherency of a crystal lattice 
with $\mathrm{Mg}$ alloy matrix [13]. Mg matrix composites reinforced with in situ $\mathrm{TiC}$ and $\mathrm{TiB}_{2}$ particles have been fabricated using self-propagating high-temperature synthesis (SHS), stir casting method and remelting and dilution (RD) [14-15]. The in-situ reactive infiltration process can be used for the synthesis of in-situ composites as an innovative process. However, a few researchers had followed this technique using $\mathrm{Ti}$ and $\mathrm{C}$ as starting materials to produce $\mathrm{TiC}$ reinforcements in Mg-based alloy matrix composites [8, 1618]. Using the starting materials $\mathrm{Ti}$ and $\mathrm{B}_{4} \mathrm{C}$ particles via a reactive infiltration technique has been found to be limited in the open literature for synthesizing the $\mathrm{Mg}$ alloy matrix $\mathrm{TiC}$ and $\mathrm{TiB}_{2}$ in-situ composites [16-19]. Thus, the present work has been performed to the synthesis of $\mathrm{Mg}$ alloy matrix composites in-situ MMCs reinforced with stable ceramic particles $\mathrm{TiC}$ and $\mathrm{TiB}_{2}$ through infiltration process using $\mathrm{Ti}$ and $\mathrm{B}_{4} \mathrm{C}$ particles as starting materials.

\section{Materials and Experimental Procedure}

\subsection{In-situ Composites Fabrication by Reactive Infiltration Technique}

Mg-Al-Zn alloy ingot (94.03 wt.\% Mg, 3.24 wt.\% $\mathrm{Al}$ and 2.40 wt.\% Zn) was used as matrix materials and coarse $\mathrm{Ti}$ (average particle size $250 \mu \mathrm{m}$ ) and $\mathrm{B}_{4} \mathrm{C}$ (average particle size $40 \mu \mathrm{m})$ powders were used as starting materials for synthesizing the in-situ $\mathrm{Mg}$ alloy composites. Ti and $\mathrm{B}_{4} \mathrm{C}$ powders with a molar ratio of $3: 1$ were taken in a polypropylene jar with $210 \mathrm{gm}$ zirconia balls. In order to prevent oxidation of $\mathrm{Ti}, \mathrm{B}_{4} \mathrm{C}$ powders and zirconia balls were taken in a Perspex box filled with Ar gas. The powders were mixed in a planetary ball mill with a speed of $400 \mathrm{rpm}$ for 4 hours. After blending, the mixture of $\mathrm{Ti}$ and $\mathrm{B}_{4} \mathrm{C}$ powders was compacted into the green preforms of the cylindrical shape of $15 \mathrm{~mm}$ diameter and various heights $(150-167 \mathrm{~mm})$ using hardened steel dies under the pressure of $80 \mathrm{Mpa}$ with the help of the universal tensile testing machine. The compacted $\mathrm{Ti}-\mathrm{B}_{4} \mathrm{C}$ preform was then placed in a perforated mild steel tube. The pieces of Mg-Al-Zn alloy ingot were placed on the top of the compacted preform in the tube. The steel tube containing powder preform and $\mathrm{Mg}$ alloy ingots was then placed in a stainless steel chamber and the chamber was then closed with the lid containing two openings where one was used as an inlet for Ar gas and another was used as an outlet. The stainless steel chamber was placed in the furnace and the chamber was purged with Ar for a few minutes before heating and then backfilled with argon gas. The infiltration process was carried out in the furnace in the presence of a continuous flow of argon gas with a flow rate of 5 L.min ${ }^{-1}$. The synthesis process was carried out at temperatures of $800^{\circ} \mathrm{C}$ and $900^{\circ} \mathrm{C}$ for 1 and 4 hours. The heating rate $13^{\circ} \mathrm{C} / \mathrm{min}$ was used to reach synthesis temperature. At the end of predetermined infiltration time, the furnace was switched off and the samples were cooled in the furnace in an argon atmosphere.

\subsection{Characterization of the Nanostructures}

The samples were polished by following standard metallographic technique and were investigated under a field emission scanning electron microscope (FESEM) equipped with Energy dispersive X-ray (EDX). For phase analysis, some selective samples were analyzed by X-ray diffraction technique using $\mathrm{Cu} \mathrm{K \alpha}$ radiation. The relative density of the synthesized composites was determined. Brinell hardness test was also carried out to determine the mechanical properties of the in-situ composites.

\section{Results and Discussion}

\subsection{Micro Structural Characterization of the In-situ Composites}

SEM micrographs of the Mg-Al-Zn alloy in-situ composites synthesized at the temperature of $800^{\circ} \mathrm{C}$ and $900^{\circ} \mathrm{C}$ for holding time 1 and 4 hours investigated using FESEM are shown in Figure 1, Figure 2 and Figure 3. Microstructures reveal that the samples infiltrated at different processing parameters contain grey particles (A), black particles (B), grey at deep ditches (C), porous structure (D) and white particles (E). The various sizes of the phases ranging from the submicron to several hundred microns are observed for all the in-situ composites.

The chemical compositions of the phases were measured by EDX analysis and the typical spectra of different phases are shown in Figure 1 (c) and Figure 1 (d). According to the EDX results, it is seen that the grey dense phases (A) consists of $0.69 \% \mathrm{~B}, 3.69 \% \mathrm{C}, 4.66 \% \mathrm{O}, 0.23 \% \mathrm{Mg}$ and $90.73 \%$ Ti while black phases (B) consists of $80.76 \% \mathrm{~B}$, $19.04 \%$ C, $0.14 \% \mathrm{O}$ and $0.06 \%$ Ti. Based on the analysis of EDX result, the grey dense phase (A) is indicated as Ti and the black particles (B) as $\mathrm{B}_{4} \mathrm{C}$. It is seen from the Figure 2, EDX analysis at spot $\mathrm{C}$ shows that grey phase at deep ditches consists of $3.32 \% \mathrm{~B}, 11.29 \% \mathrm{C}, 20.73 \% \mathrm{O}, 5.79 \%$ $\mathrm{Mg}$ and $58.87 \% \mathrm{Ti}$ while the porous structure (spot $\mathrm{D}$ ) consists of $7.58 \% \mathrm{~B}, 31.09 \% \mathrm{O}, 61.08 \% \mathrm{Mg}$ and $0.25 \% \mathrm{Ti}$. Grey phase at deep ditches (spot C) in the matrix is indicated to be infiltrated $\mathrm{Mg}$ but the porous structure (spot D) is basically B, C, O and Ti enriched structure. This $\mathrm{O}$ is due to the oxidation of $\mathrm{Mg}$ which may be produced during polishing.

From the Figure 3, spot E consists of $1.69 \%$ B, $13.71 \% \mathrm{C}$, $57.35 \% \mathrm{O}, 26.70 \% \mathrm{Mg}$ and $0.55 \% \mathrm{Ti}$. Some bright white small particles $(\mathrm{E})$ observed in the matrix through infiltrated in-situ composites as an oxide of $\mathrm{Mg}$ is identified. At least eight spots analysis from each of the phases of the in-situ composites synthesized at different temperature and time were taken and an average value of above-mentioned phases is given in Table 1 . 



Figure 1. Showing SEM image of Mg alloy in-situ composites synthesized at $800^{\circ} \mathrm{C}$ for (a) $1 \mathrm{hr}$ and (b) $4 \mathrm{hr}$, and EDX spectra of (c) spot A and (d) spot B in the image.
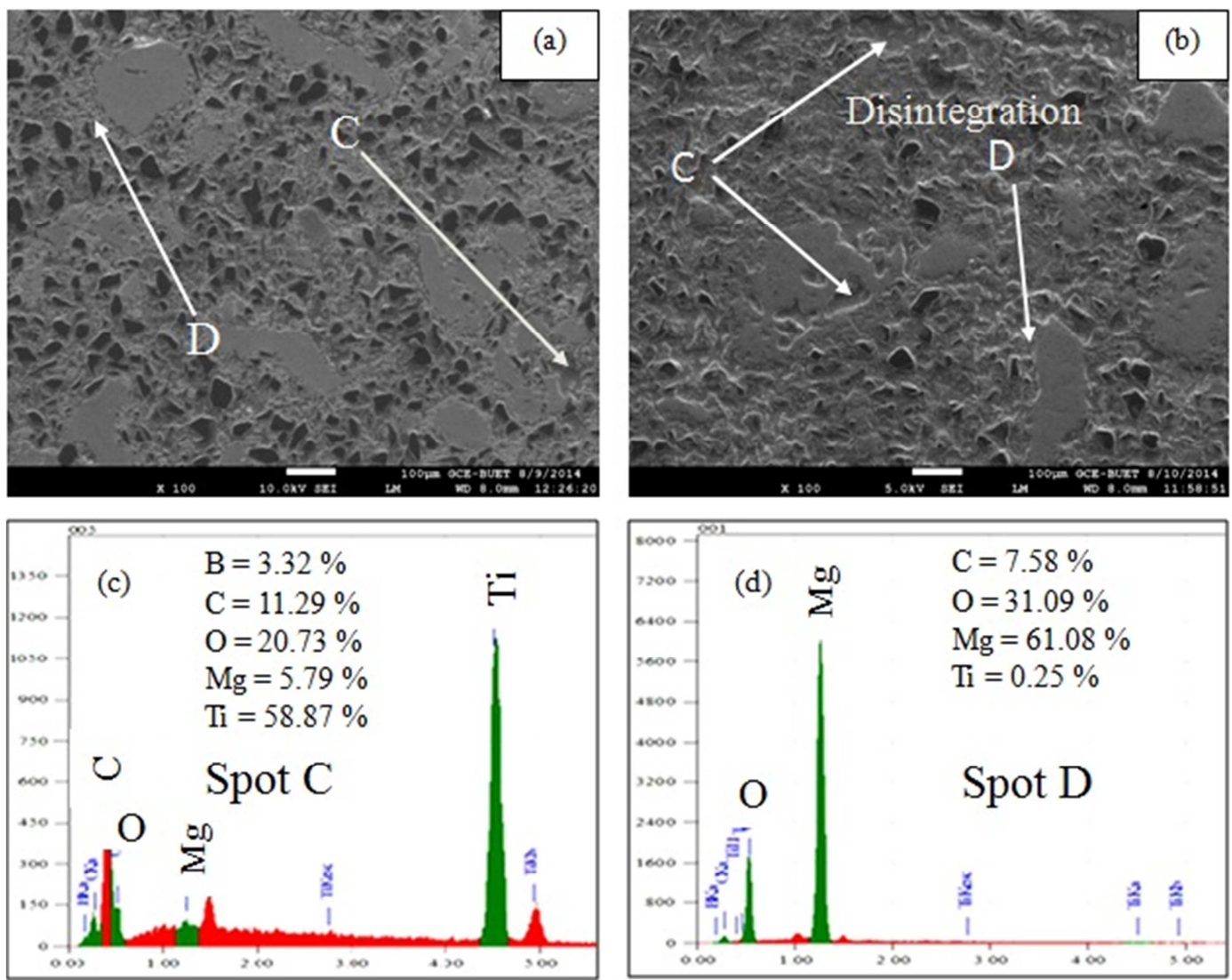

Figure 2. Showing SEM image of Mg alloy in situ composites synthesized at $900^{\circ} \mathrm{C}$ for (a) $1 \mathrm{hr}$ and (b) $4 \mathrm{hr}$, and EDX spectra of (c) spot C and (d) spot D in the image. 

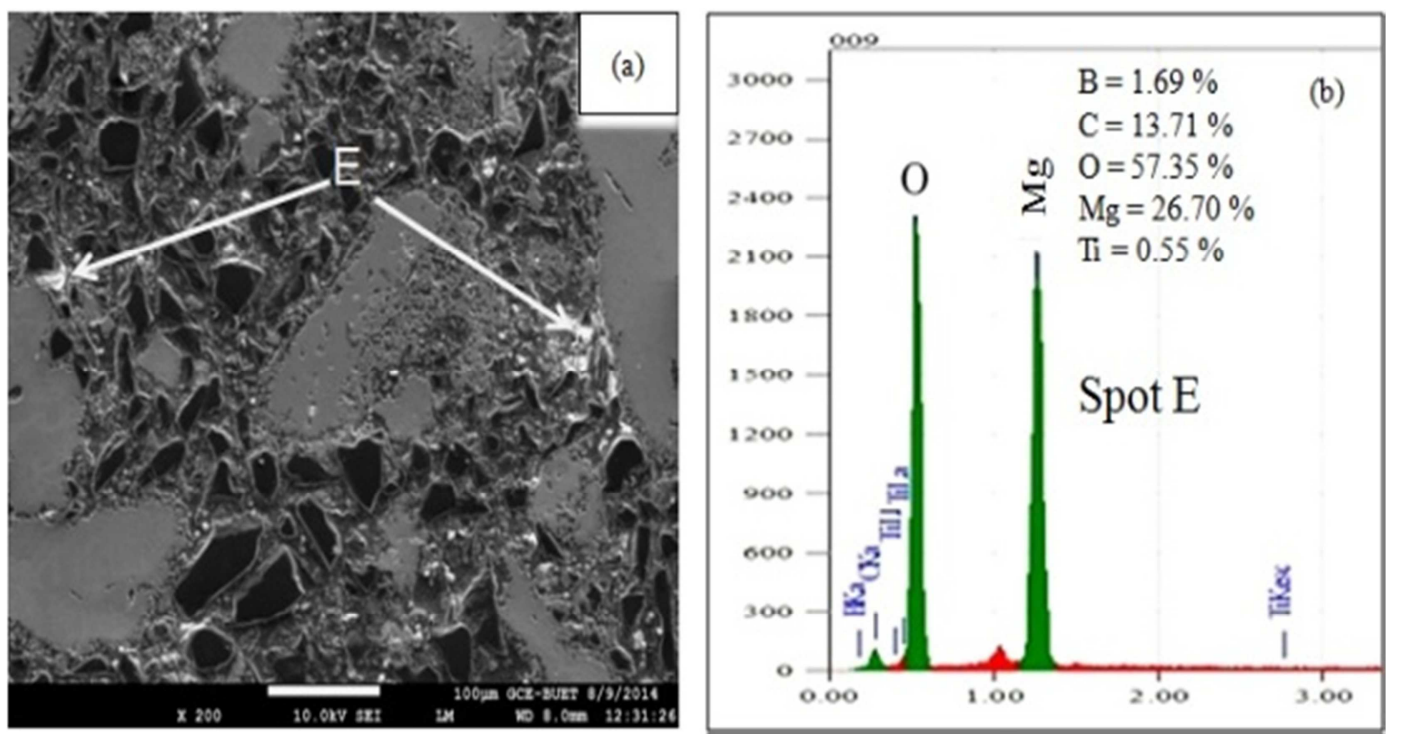

Figure 3. Showing (a) SEM image of Mg alloy in-situ composites synthesized at $900^{\circ} \mathrm{C}$ for $1 \mathrm{hr}$, and EDX spectra of (b) spot E in the image.

Table 1. Chemical composition of different phases present in Mg-Al-Zn alloy in-situ composites synthesized at different temperatures and time.

\begin{tabular}{llllll}
\hline Phase & B (wt.\%) & C (wt.\%) & O (wt.\%) & Mg (wt.\%) & Ti (wt.\%) \\
\hline Grey particles (A) & 1.31 & 3.33 & 14.51 & 0.72 & 80.13 \\
Black particles (B) & 82.83 & 16.81 & 0.11 & 0.04 & 0.21 \\
Grey phase at deep ditches (C) & - & 11.99 & 22.34 & 65.26 & 0.41 \\
Porous structure (D) & 17.53 & 8.78 & 14.34 & 3.18 & 56.17 \\
White particle (E) & - & 15.97 & 57.89 & 26.08 & 0.06 \\
\hline
\end{tabular}

It is observed from Figure 1 (b) and Figure 2 (b), Ti phase is disintegrated with the rise of the holding time [compare Figure 1 (a) and Figure 1 (b)] and temperatures [compare Figure 1(b) and Figure 1 (d)] because more reactions occur and new compounds are formed in a large quantity. From the micrographs, it is observed that the extent of disintegration of $\mathrm{Ti}$ and $\mathrm{B}_{4} \mathrm{C}$ and reactions are found to be the highest at the infiltration temperature of $900^{\circ} \mathrm{C}$ for 4 hours (Figure 2d). The disintegration of the vicinity of the Ti phases is normally higher in the $\mathrm{Mg}$ alloy in-situ composites because the addition of $\mathrm{Al}$ in $\mathrm{Mg}$ acts as a reaction intermediary to facilitate the reaction between $\mathrm{Ti}$ and $\mathrm{B}$ or $\mathrm{Ti}$ and $\mathrm{B}_{4} \mathrm{C}$ [20]. It was reported that $\mathrm{Al}$ addition to the $\mathrm{Ti}-\mathrm{C}$ preform enhances the reaction between $\mathrm{Ti}$ and $\mathrm{C}$ in $\mathrm{Mg}$ alloy [21]. The viscosity and wettability facilitate $\mathrm{Mg}$ alloy in infiltration through the preform of $\mathrm{Ti}^{-} \mathrm{B}_{4} \mathrm{C}$ to form the in-situ $\mathrm{TiC}$ compared to the performance of $\mathrm{Mg}$ in-situ composites. As a result, more infiltration of $\mathrm{Mg}$ alloy into the pores of the Ti- $\mathrm{B}_{4} \mathrm{C}$ preform conducted by the capillary force results in the densified microstructure of in-situ composites.

\subsection{XRD Analysis of In-situ Composites}

The XRD pattern of the samples of Mg-Al-Zn alloy infiltrated in the Ti- $\mathrm{B}_{4} \mathrm{C}$ preforms at $800^{\circ} \mathrm{C}$ and $900^{\circ} \mathrm{C}$ for 4 hours is shown in Figure 4. From the XRD pattern analysis of the in- situ composites, $\mathrm{MgB}_{2}, \mathrm{MgB}_{4}, \mathrm{TiC}, \mathrm{TiB}, \mathrm{TiB}_{2}, \mathrm{~B}_{13} \mathrm{C}_{3}$ and $\mathrm{Ti}_{2} \mathrm{AlC}$ phases are identified in addition to the starting materials of $\mathrm{Ti}, \mathrm{B}_{4} \mathrm{C}$ and $\mathrm{Mg}$ alloy. It was reported that $\mathrm{C}$ - saturated $\mathrm{Ti},\left(\mathrm{Ti}_{\mathrm{C}}-\mathrm{sat}\right)$, formed prior to titanium carbide due to the diffusion of $\mathrm{C}$ from $\mathrm{B}_{4} \mathrm{C}$ into Ti.

With increasing temperature, the substoichiometric TiC forms while the lattice parameters of the retained $\mathrm{Ti}$ were decreased. The range of the lattice parameters of the boron carbide is found to be consistent with that of the standard lattice constants of $\mathrm{B}_{13} \mathrm{C}_{2}$ according to Pearson's Handbook [22]. Based on the results and the crystallographic data of phases from Pearson's handbook [22], the reaction sequence of the Ti- $\mathrm{B}_{4} \mathrm{C}$ system can be presented as follows:

$$
\begin{aligned}
3 \mathrm{Ti}+\mathrm{B}_{4} \mathrm{C} & =\mathrm{TiC}-\mathrm{sat}+\mathrm{B}_{13} \mathrm{C}_{2} \rightarrow \mathrm{TiC}-\mathrm{sat}+\mathrm{B}_{13} \mathrm{C}_{2}+\mathrm{TiC} \\
& \rightarrow \mathrm{Ti}+\mathrm{B}_{13} \mathrm{C}_{2}+\mathrm{TiC}+\mathrm{TiB} \\
& \rightarrow \mathrm{Ti}+\mathrm{B}_{13} \mathrm{C}_{2}+\mathrm{TiC}+\mathrm{TiB}+\mathrm{Ti}_{3} \mathrm{~B}_{4} \\
\rightarrow \mathrm{B}_{13} \mathrm{C}_{2} & +\mathrm{TiC}+\mathrm{TiB}+\mathrm{TiB}_{2}+\mathrm{Ti}_{3} \mathrm{~B}_{4} \rightarrow \mathrm{TiC}+\mathrm{TiB}_{2}
\end{aligned}
$$

The formation of substoichiometric $\mathrm{TiC}$ prior to the titanium borides was proposed by Zhao and Chang [23]. This attribute to the diffusivity of carbon in $\mathrm{Ti}$ was being much greater than that of boron [24]. Despite strong covalent bonds between the atoms in the boron carbide structure, carbon diffused away from boron carbide faster than that of boron. Thus $\mathrm{TiC}$ phase formed prior to titanium borides liberating a B-rich boron carbide $\mathrm{B}_{13} \mathrm{C}_{2}$ as it is also evident in XRD analysis in $\mathrm{Mg}$ matrix system. This was also reported by Shen et al. [24-25]. 


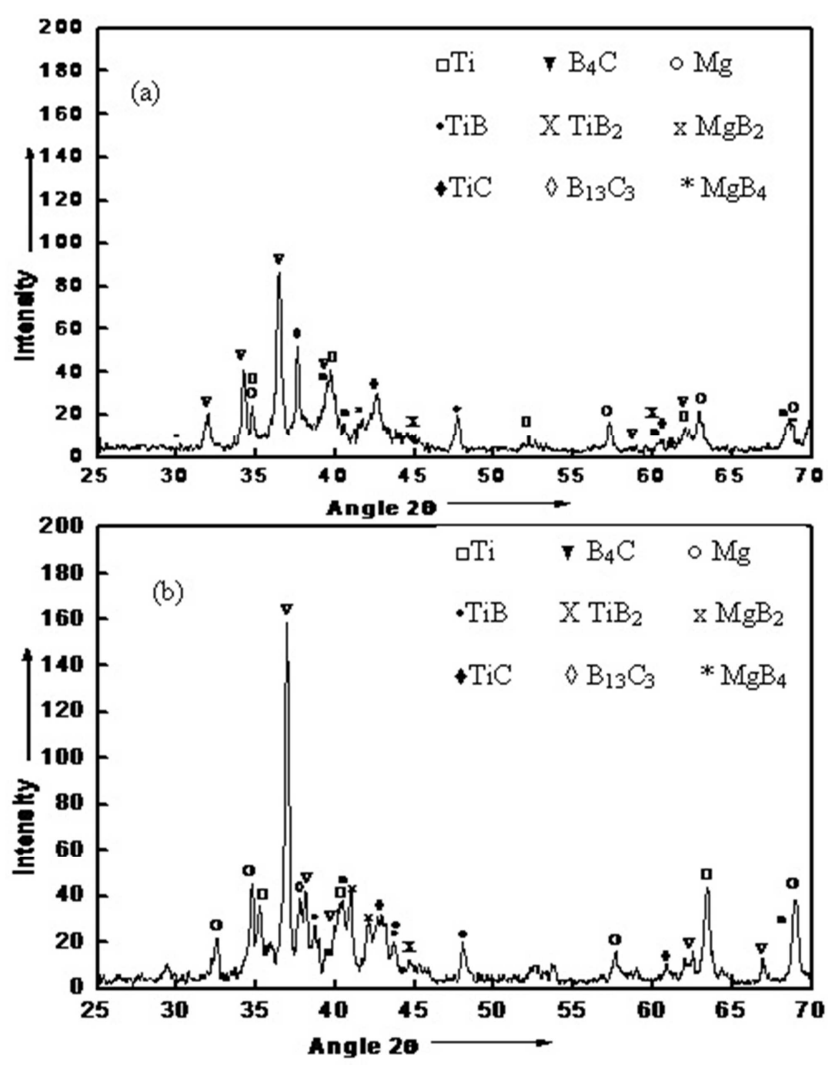

Figure 4. XRD patterns of heat treated $M g-A l-Z n-(T i-B 4 C)$ samples synthesized at different temperatures of (a) $800^{\circ} \mathrm{C}$ and (b) $900^{\circ} \mathrm{C}$ after 4 hour holding time.

Based on the $\mathrm{XRD}$ results, it can be suggested that molten magnesium alloy reacts with $\mathrm{B}_{4} \mathrm{C}$ to form magnesium diboride liberating carbon as the following reaction. Kevorkijian and Skapin revealed the same [26]. This reaction is an exothermic reaction evolving heat for further reaction to occur in the system. Hence, the reaction mechanism is as follows:

$$
2 \mathrm{Mg}+\mathrm{B}_{4} \mathrm{C}=2 \mathrm{MgB}_{2}+\mathrm{C}
$$

The presence of $\mathrm{MgB}_{4}$ peaks in the XRD pattern is also observed because $\mathrm{MgB}_{2}$ partially decomposes forming $\mathrm{MgB}_{4}$ and $\mathrm{Mg}$ gas that diffuses through the thin film of $\mathrm{MgB}_{4}$ as follows:

$$
\mathrm{MgB}_{2}=1 / 2 \mathrm{MgB}_{4}+1 / 2 \mathrm{Mg}(\mathrm{g})
$$

This agrees with the results obtained by Brutti et al. [27]. $\mathrm{TiC}$ is formed due to the reaction between $\mathrm{Ti}$ and $\mathrm{B}_{4} \mathrm{C}(1)$ and also the diffusion of atomic $\mathrm{C}$ liberated from the reaction between $\mathrm{Mg}$ and $\mathrm{B}_{4} \mathrm{C}$ (3) into Ti according to the following equation:

$$
\begin{gathered}
3 \mathrm{Ti}+\mathrm{B}_{4} \mathrm{C}+\mathrm{Mg}=\mathrm{Ti}+\mathrm{B}_{13} \mathrm{C}_{2}+\mathrm{TiC}+\mathrm{TiB}+\mathrm{Ti}_{3} \mathrm{~B}_{4}+\mathrm{MgB}_{2}+ \\
\mathrm{MgB}_{4} \\
\rightarrow \mathrm{B}_{13} \mathrm{C}_{2}+\mathrm{TiC}+\mathrm{TiB}+\mathrm{Ti}_{3} \mathrm{~B}_{4}+\mathrm{TiB}_{2}+\mathrm{MgB}_{2} \\
\text { Where: } \mathrm{Ti}+1 / 2 \mathrm{MgB}_{4}=2 \mathrm{TiB}_{2}+3 / 2 \mathrm{Mg}
\end{gathered}
$$

Since $\mathrm{MgB}_{2}$ reacts with $\mathrm{TiB}$ forming $\mathrm{TiB}_{2}, \mathrm{TiB}$ and $\mathrm{Ti}_{3} \mathrm{~B}_{4}$, react with the retained boron carbide as presented earlier in the reaction mechanism of a $\mathrm{Ti}-\mathrm{B}_{4} \mathrm{C}$ system, the reaction between $\mathrm{Ti}, \mathrm{B}_{4} \mathrm{C}$, and infiltrated molten $\mathrm{Mg}$ alloy is finally obtained as follows:

$$
\mathrm{Ti}+\mathrm{B} 4 \mathrm{C}+\mathrm{Mg} \rightarrow \mathrm{TiC}+\mathrm{TiB} 2+\mathrm{Mg}
$$

It is found in XRD pattern that TiC formed at first in both the samples while the percentage of $\mathrm{TiB}_{2}$ increased with increasing synthesis temperature, and this is clear when comparing the peaks of the phases because of a strong effect of processing temperature on increasing the in situ reaction rate in XRD. Only one ternary compound $\mathrm{Ti}_{2} \mathrm{AlC}$ is also identified in $\mathrm{Mg}$ alloy composites synthesized at both temperatures and time. But, at a higher temperature, the $\mathrm{Ti}_{2} \mathrm{AlC}$ peak is found to be increased. This peak is formed due to the presence of $\mathrm{Al}$ in the alloy which reacts with $\mathrm{Ti}$ and dissociated $\mathrm{C}$ from $\mathrm{B}_{4} \mathrm{C}$. The atomic bonding in the ternary compound is a combination of metallic, ionic and covalent [28]. The covalent-ionic Ti-C bonds are comparable to bonds in the binary $\mathrm{TiC}$ but they are stronger than the metallic Ti-Al bonds in the ternary structure [28]. Because of the relatively weak bonds between the $\mathrm{TiC}$ and $\mathrm{Al}$ layers in the basal planes, these materials have an anisotropic character [29].

$\mathrm{MgB}_{2}, \mathrm{MgB}_{4}, \mathrm{TiC}, \mathrm{TiB}, \mathrm{TiB}_{2}$, and $\mathrm{B}_{13} \mathrm{C}_{2}$ are found in both the in situ composites synthesized in the present study. It was also reported that the compounds of $\mathrm{MgB}_{2}, \mathrm{MgB}_{4}, \mathrm{TiB}$, and $\mathrm{B}_{13} \mathrm{C}_{2}$ were thermodynamically unstable and these are known as intermediate compounds [30]. These compounds dissociate and form the more stable compounds $\mathrm{TiC}$ and $\mathrm{TiB}_{2}$ $[11-12,31]$. In the present case, the presence of $\mathrm{Ti}$ and $\mathrm{B}_{4} \mathrm{C}$ with intermediate compound $\mathrm{MgB}_{2}, \mathrm{MgB}_{4}, \mathrm{TiB}$ and $\mathrm{B}_{13} \mathrm{C}_{2}$ in the both in situ composites indicates that the reactions were incomplete.

\subsection{Effect of Temperature and Time on Relative Density}

The relative density of $\mathrm{Mg}$ alloy in-situ composites synthesized at $800^{\circ} \mathrm{C}$ for 1 and 4 hours, and $900^{\circ} \mathrm{C}$ for 1 and 4 hours shows $2.50 \mathrm{gm} / \mathrm{cm}^{3}, 2.68 \mathrm{gm} / \mathrm{cm}^{3}, 2.60 \mathrm{gm} / \mathrm{cm}^{3}$ and $2.77 \mathrm{gm} / \mathrm{cm}^{3}$, respectively. It also shows that the relative density increases with increasing infiltration temperature and time. With increasing temperature, more $\mathrm{Mg}$ alloy is infiltrated into the preform by capillary action and yields to high density. The small addition of $\mathrm{Al}$ from $\mathrm{Mg}-\mathrm{Al}-\mathrm{Zn}$ alloy increases the wettability of $\mathrm{Mg}$ and infiltration into the preforms with increasing holding time [20-21, 32]. Secondly, the presence of a lot of carbon vacancies in the TiC structure orderly can help $\mathrm{Al}$ to fill the spaces forming a ternary compound $\mathrm{Ti}_{2} \mathrm{AlC}$ [33-34]. This ternary compound may form due to the diffusion of $\mathrm{Al}$ from the $\mathrm{Mg}-\mathrm{Al}-\mathrm{Zn}$ alloy melt into the sub-stoichiometric $\mathrm{TiC}$ compound in the in-situ composites infiltrated with the rise of infiltration time.

\subsection{Effect of Temperature and Time on Hardness}

Brinell hardness of $\mathrm{Mg}$ alloy matrix in-situ composites using $\mathrm{Ti}-\mathrm{B}_{4} \mathrm{C}$ preform infiltrated at different processing parameters is presented in Table 2. It is observed that the 
hardness of Mg alloy infiltrated in-situ composites increases with the increase of temperature and time. More $\mathrm{Mg}$ alloy infiltration into the preforms by capillary action make the insitu composites dense and simultaneously more reaction products formed at high temperature and time with the higher amount of stable $\mathrm{TiC}$ and $\mathrm{TiB}_{2}$. High infiltration temperature and time resulted in high infiltration and high intermediate compounds with stable $\mathrm{TiC}$ and $\mathrm{TiB}_{2}$.

Table 2. Brinell hardness values of Mg alloy matrix in-situ composites using Ti-B ${ }_{4} C$ preform infiltrated at different processing temperature and time.

\begin{tabular}{lll}
\hline Temperature $\left({ }^{\circ} \mathbf{C}\right)$ & Time (hr) & Brinell hardness \\
\hline \multirow{2}{*}{800} & 1 & 127 \\
& 4 & 191 \\
\multirow{2}{*}{900} & 1 & 142 \\
& 4 & 198 \\
\hline
\end{tabular}

\section{Conclusion}

Reactive infiltration process was used to synthesize $\mathrm{Mg}$ alloy matrix in-situ composites. The infiltration of $\mathrm{Mg}$ in Ti$\mathrm{B}_{4} \mathrm{C}$ preform was evident from the SEM investigation and increment of relative density with infiltration temperature and time. Different types of stable and unstable compounds such as $\mathrm{MgB}_{2}, \mathrm{MgB}_{4}, \mathrm{TiB}, \mathrm{TiC}, \mathrm{TiB}_{2}$, and $\mathrm{B}_{13} \mathrm{C}_{2}$ are formed in the in situ composites during the infiltration process. The reactions in the in situ composites at synthesizing temperature and time used in the study were found to be incomplete as the evidence of the presence of intermediate compounds. The dissolution of less stable intermediate compounds will be changed into thermodynamically stable $\mathrm{TiC}$ and $\mathrm{TiB}_{2}$ using high infiltration time at high temperature. The hardness of the composites was found to increase with the infiltration temperature and time.

\section{Acknowledgements}

The authors acknowledge the financial support of the Committee for Advanced Studies and Research (CASR), Bangladesh University of Engineering and Technology (BUET) and the opportunity for SEM investigation given by Glass and Ceramics Engineering (GCE) Department, BUET, Dhaka-1000, Bangladesh.

\section{References}

[1] M. Kulekci. Magnesium and its alloys applications in automotive industry, The International Journal of Advanced Manufacturing Technology, Vol. 39, No. 9, 2008, pp. 851-865.

[2] Metin Onal, Mehmet Gavgali. Production of Metal Matrix Composites by In-situ Techniques, Journal of Scientific and Engineering Research, 2017, 4(2):78-82.

[3] Zhaoxuan Wu \& W. A. Curtin, The origins of high hardening and low ductility in magnesium, International Journal of Science, Nature volume 526, pages 62-67 (01 October 2015).

[4] S. F. Hassan and M. Gupta, Development of a novel magnesium-copper based composite with improved mechanical properties, Materials Research Bulletin, Vol. 37, No. 2, 2002, pp. 377-389.

[5] Q. C. Jiang, X. L. Li, and H. Y. Wang. Fabrication of TiC particulate reinforced magnesium matrix composites, Scripta Materialia, Vol. 48, No. 6, 2003, pp. 713-717.

[6] B. L. Mordike and T. Ebert. Magnesium: Propertiesapplications-potential, Materials Science and Engineering, A, Vol. 302, No. 1, 2001, pp. 37-4.

[7] H. Y. Wang, Q. C. Jiang, X. L. Li, J. G. Wang, Q. F. Guan and H. Q. Liang. In-situ synthesis of TiC from nanopowders in molten magnesium alloy, Materials Research Bulletin, Vol. 38, No. 8, 2003, pp. 1387-1392.

[8] Abhijit Dey and Krishna Murari Pandey, Magnesium Metal Matrix Composite- A Review, Rev. Adv. Mater. Sci. 42 (2015) 58-67.

[9] Y. Wang, H. Y. Wang, K. Xiu, H. Y. Wang and Q. C. Jiang. Fabrication of $\mathrm{TiB}_{2}$ Particulate reinforced magnesium matrix composites by two-step processing method, Materials Letters, Vol. 60, No. 12, 2006, pp. 1533-1537.

[10] L. Q. Chen, Q. Dong, M. J. Zhao, J. Bi and N. Kanetake. Synthesis of $\mathrm{TiC} / \mathrm{Mg}$ composites with interpenetrating networks by in-situ reactive infiltration process, Materials Science and Engineering: A, Vol. 408, No. (1-2), 2005, pp. 125-130.

[11] G. Wen, S. B. Li, B. S. Zhang and Z. X. Guo. Reaction synthesis of $\mathrm{TiB}_{2}$-TiC composites with enhanced toughness, Acta Materialia, Vol. 49, No. 8, 2001, pp. 1463-1470.

[12] W. J. Li, R. Tu, and T. Goto, Preparation of directionally solidified $\mathrm{TiB}_{2}$-TiC eutectic composites by a floating zone method, Materials Letters, Vol. 60, No. 6, 2006, pp. 839-843.

[13] X. Zhang, H. Wang, L. Liao, and N. Ma: New Synthesis Method and Mechanical Properties of Magnesium Matrix Composites, Journal of ASTM International, 2005, Vol. 3, No. 10. Paper No: JA1100618.

[14] B. Ma, H. Wang, Y. Wang, and Q. Jiang. Fabrication of ( $\mathrm{TiB}_{2^{-}}$ TiC) p/AZ91 magnesium matrix hybrid composite, Journal of Materials Science, Vol. 40, No. 17, 2005, pp. 4501-4504.

[15] K. N. Braszczynska-Malik, E. Przelozynska, Fabrication of AM50 magnesium matrix composite with titanium particles by stir casting method, Inzynieria Materiałowa 3 (211) (2016) 115-119.

[16] W. Cao, C. Zhang, T. Fan, and D. Zhang. In-Situ Synthesis and Compressive Deformation Behaviors of TiC Reinforced Magnesium Matrix Composites, Materials Transactions, Vol. 49, No. 11, 2008, pp. 2686-2691.

[17] A. Chaubey, B. Mishra, N. Mukhopadhyay, and P. Mukherjee. Effect of compact density and preheating temperature of the Al-Ti-C preform on the fabrication of in-situ Mg-TiC composites, Journal of Materials Science, Vol. 45, No. 6, 2010, pp. 1507-1513.

[18] D. Qun, L. Chen, Z. Mingiiu and B. Jing. Analysis of in-situ reaction and pressureless infiltration process in fabricating $\mathrm{TiC} / \mathrm{Mg}$ composites, Journal of Materials Science and Technology, Vol. 20, 2004, pp. 3-7.

[19] L. Chen, J. Guo, B. Yu, and Z. Ma. Compressive Creep Behavior of TiC/AZ91D Magnesium-matrix Composites with Interpenetrating Networks, Journal of Materials Science and Technology, Vol. 23, No. 2, 2007, pp. 207-212. 
[20] N. Chawla and K. K. Chawla: Metal Matrix Composites, Springer and Business Media, Inc., New York, 2006.

[21] M. A. Matin, L. Lu, and M. Gupta: Investigation of the reactions between boron and titanium compounds with magnesium, Scripta Materialia, Vol. 45, No. 4, 2001, pp. 479-486.

[22] H. putz and K. Brandenburg: Pearson's Crystal Structure Database for Inorganic compound, CD-ROM software version 1.3.

[23] H. Zhao, and Y. B. Cheng: Formation of $\mathrm{TiB}_{2}-\mathrm{TiC}$ composites by reactive sintering, Ceramics International, Vol. 25, No. 4, 1999, pp. 353-358.

[24] P. Shen, B. Zou, S. Jin, and Q. Jiang: Reaction mechanism in self-propagating high temperature synthesis of $\mathrm{TiC}^{-\mathrm{TiB}_{2} / \mathrm{Al}}$ composites from an Al-Ti- ${ }_{4} \mathrm{C}$ system, Materials Science and Engineering: A, Vol. 454-455, 2007, pp. 300-309.

[25] D. Emin: Structure and single-phase regime of boron carbides, Journal of Review Letters B, Vol. 38, 1988, pp. 6041-6055.

[26] V. Kevorkijan, and S. D. Skapin $\mathrm{Mg}-\mathrm{B}_{4} \mathrm{C}$ composites with a high volume fraction of fine ceramic reinforcement, Journal of Materials and Manufacturing processes, Vol. 24, 2009, pp. 1337-1340.

[27] S. Brutti, G. Balducci, G. Gigli, A. Ciccioli, P. Manfrinetti, and A. Palenzona: Thermodynamic and kinetic aspects of decomposition of $\mathrm{MgB}_{2}$ in vacuum: Implications for optimization of synthesis conditions, Journal of Crystal Growth, Vol. 289, No.2, 2006, pp. 578-586.
[28] Y. Zhou and Z. Sun: Electronic structure and bonding properties of layered machinable $\mathrm{Ti}_{2} \mathrm{AlC}$ and $\mathrm{Ti}_{2} \mathrm{AlN}$ ceramics, Physical Review B, Vol. 61, No. 19, 2000, pp. 12570-12573.

[29] Z. Sun, D. Music, R. Ahuja, S. Li, and, J. M. Schneider: Bonding and classification of nanolayered ternary carbides, Physical Review B, Vol. 70, No. 9, 2004, pp. 1-3.

[30] Y. Wang, H. Y. Wang, B. X. Ma, K. Xiu, and Q. C. Jiang: Effect of $\mathrm{Ti} / \mathrm{B}$ on fabricating $\mathrm{TiB}_{2} \mathrm{p} / \mathrm{AZ} 91$ composites by employing a $\mathrm{TiB}_{2} \mathrm{p} / \mathrm{Al}$ master alloy, Journal of Alloys and Compounds, Vol. 422, no. (1-2), 2006, pp. 178-183.

[31] R. J. LaBotz and D. R. Mason: The thermal conductivities of $\mathrm{Mg}_{2} \mathrm{Si}$ and $\mathrm{Mg}_{2} \mathrm{Ge}$, Journal of the Electrochemical Society, Vol. 110, No. 2, 1963, pp. 121-126.

[32] W. B. Zhou, B. C. Mei, and J. Q. Zhu: Rapid reactive synthesis of $\mathrm{Ti}_{2} \mathrm{AlC}-\mathrm{TiB}_{2}$ composites by spark plasma sintering, Journal of Ceramic Processing Research, Vol. 10, No. 1, 2009, pp. 102-104.

[33] H. Holleck, H. Leiste, E. Nold, H. Schulz, and A. Skokan: Multiphase ceramic materials and coatings for fusion reactor applications, Journal of Nuclear Materials, Vol. 155-157, No. 1, 1988, pp. 221-224.

[34] H. O. Pierson: Handbook of Refractory Carbides and Nitrides, Noyes Publications, Westwood, New Jersey, USA, 1996. 